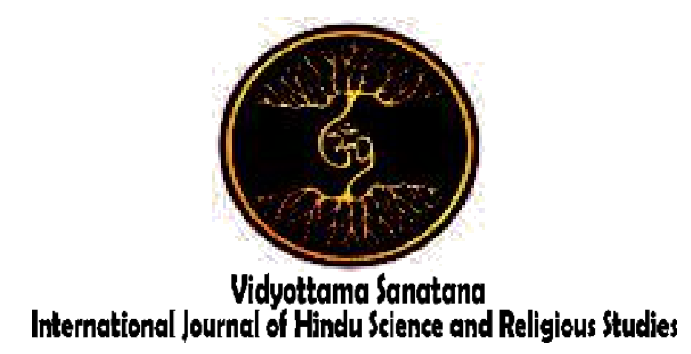

Vol. 4 No. 1 May 2020

\title{
TEACHING EDUCATION VALUES OF HINDU RELIGIOUS THROUGH SATUA I LACUR
}

\author{
By: \\ Ni Nyoman Perni ${ }^{1}$, I Ketut Sudarsana ${ }^{2}$ \\ ${ }^{12}$ Universitas Hindu Negeri I Gusti Bagus Sugriwa Denpasar \\ E-mail : ${ }^{1}$ nyomanperni80@gmail.com, ${ }^{2}$ iketutsudarsana@uhnsugriwa.ac.id
}

Received: April 4, 2020

Accepted: May 12, 2020

Published: May 30, 2020

\begin{abstract}
This study aims to describe the teaching education value of the Hindu religion through Satua I Lacur for elementary school students in Denpasar City. Based on the analysis, the results obtained; 1) Teaching education values of Hindu religion through Satua I Lacur as a teaching medium can deliver noble values. Teaching with satua / stories to students will provide a pleasant learning atmosphere. When students listen to the story / Satua I Lacur, some scenes cause feelings of compassion and pleasure. These feelings emerge as appreciation of the storyline. So indirectly the students' appreciation of the characters can provide an ethical education in the education value of tattwa and karmaphala. 2) Educational values in Satua I Lacur are principles and ethics. The value of tattwa in satua describes a gentle character, never angry, and innocent so that I Lacur is always calm. This shows the character of wisdom. In addition, it drew the ethical values from the Satua I Lacur character in describing noble deeds and always behave based on the teachings of Tri Kaya Parisudha namely positive thinking, good saying, and doing good.
\end{abstract}

Keywords: Hindu Religious Education Values; Satua I Lacur; Elementary School Students.

\section{INTRODUCTION}

Bali is a place which famous for its art and culture, one of which includes as Balinese literature is satua. Satua Bali is Balinese literature which in its delivery uses oral language and rich of noble educational values such as religious, cultural, ethical or moral, artistic, and tattwa or philosophy values. According to Duija and Prima Dewi PF, Satua Bali is not only a solace tradition but become a topic of environmental communication in various situations. It is as a form of 
strengthening the existence of the surrounding environment from human distruction, despite the positive laws governing it. Satua Bali (folklore) is a variety of traditional Balinese literature (Duija \& Dewi PF, 2019). Most people have forgotten the traditional stories, and satua is rich with the noble values of Hindu education. Society especially parents are sometimes confused and can not decide what story to be shared to children. Modernization has affected most people, experiencing development and progress, assuming that Satua is something ancient and out of date.

Balinese has many fairytale (satua), like satua I Siap Selem, I Belog, I Cupak teken I Grantang, Men Sugih teken Men Tiwas, Ni Bawang Teken Ni Kesuna, I Kambing Takutin Macan, Ni Tuwung Kuning, I Rare Angon, Pan Balang Tamak, Sampik Ingtai, Tuma teken Titih, I Klesih, I Lacur, I Cicing Gudig, Lutung teken Kambing, I Yuyu Malaksana Melah, Angsa teken Empas, Crukcuk Kuning, Bagus Diarsa, I Lubdaka, I Lutung Dadi Pecalang, I Ubuh, Sang Lanjana and others. All of these will make students interested in reading because the story is interesting. Besides, it is rich of character values that students can imitate that (Mustika, 2019).

Satua Bali especially satua I Lacur has many values of Hindu religious education so that it needs to be explored, developed, rooted back to society. Therefore, they can perform as a medium of education and children can choose a good path to follow and a bad path to be avoided. Satua Bali especially satua I Lacur, is not only as an entertainer for children, but as teachings for its listeners. Let alone for children who lack education in a formal and informal school such as mentally retarded, mindset, intellectually, so it is difficult for them to get along in social life. It is in line with Lacur's characterization, which is stupid, innocent and poor. So that he cannot distinguish between good deeds to do and bad deeds to be avoided.

Satua is usually told when children are asleep or in today's terms lulling children. Satua is a term in Balinese to designate literary works of fairy tales. Satua is a prose of people's story that is not real happened. Satua is told mainly for entertainment, although many also describe truth, lessons (morals), or even satire. There are moral messages which are expected to be a guideline for the community to act and behave under satua teachings. Satua is also explained the good and bad deeds and the causes and consequences arising from an action taken (Dias Febriadiana, 2018). In presenting satua Bali, besides entertaining children before going to sleep, the satua Bali is usually to be contested preserving traditional or regional culture, especially mesatua Bali, because satua which has the noble values of Hindu Religion can be a role model, a guideline to teach children as the next generation in thinking and well-behaving.

Satua Bali is one of the subjects taught as supplementary reading, especially in elementary schools. In the learning process, a teacher's task is to make students master the language learned well, but they also have cultural tasks. This implies that Satua Bali teachings will accomodate that need because it can introduce Indonesian and Balinese culture.

As a forim of the subject, Satua Bali is rich with educational values that can teach ethics to students. By practicing the values in Satua Bali, we expect students to be a virtuous individual and have character. Education makes people more advanced in thinking about their lives, with education, a person will get knowledge, skills, and attitudes that make life more empowered in society (Fakhruddin, 2019). Education is a means of shaping one's character to create quality and competitive human resources. To achieve this goal, it needs cooperation from various sectors including government, education, stakeholders, and families. Learning mathematics is a process of interaction between the teacher and students to get new information 
related to mathematical knowledge, to change the mindset and behavior of students (Lestiawati \& Muthmainnah, 2019).

Balinese mesatua culture is very rare lately. As an effort to support the diversity of Balinese culture, elementary schools in Denpasar City are seeking a program called using Satua Bali as a teaching medium to teach the values of ethical education to students. All children's imagination and creativity will be devoted to make construction (Sari, Rahmatunnisa, Bahfen, \& Fauziah, 2019). Aside from an effort to preserve culture, the selection of Satua Bali as a teaching medium is very effective as it can develop the potential of the students, the reasoning and provide a condusive atmosphere during the teaching and learning. It also directs students to express and appreciate each role/character in Satua Bali. Of the various titles and types of satua, teachers in elementary schools in Denpasar selected titled "I Lacur" This selection is based on the consideration that satua "I Lacur" is prevalent in people's lives so that it can provide convenience for students in understanding the contents of the story. Also, considering the existence of legend narrative, especially satua-satua Bali, is increasingly marginalized because of the progress of science and technology that can display a variety of children's entertainment stories. The noble values in satua I Lacur should still be shared to raise the morale-ethics of society, especially students. There needs to be a systematic effort for the sake of preserving the legendary noble values.

\section{METHOD}

Research on the context of teaching values of Hindu religious education through Satua I Lacur for elementary school students in Denpasar City was a field research in a descriptive analysis. Data collection techniques used observation, interviews and literature study.
All data were analyzed using steps such as (a) editing data and coding data for data obtained using classification, (b) classifying data collection based on the codes provided to make data groupings, (c) review the completeness collected in each group and then consider the further steps needed: need to be re-variation, complete it with other data sources or other steps, (d) examine the necessary data collection from the beginning by analyzing, synthesizing, interpreting, explaining and concluding, (e) reducing and classifying data to see trends in teaching Hindu religious education contextual, and (f) concluding the research results after first verifying the data and supporting the process of inference by cross-check between data obtained with other techniques (data triangulation)

\section{RESULTS AND DISCUSSION}

1. Structure and Synopsis of Satua I Lacur

Satua Bali volume II B was issued and published by the Provincial Government of the Province of Bali. Project for preparing texts and the printing of textbooks, storybooks and literature books are in the Region Level 1 Bali in 1986/1987.

It was told that in the village named Daha, there was a child named I Lacur. He was an orphan who lived alone. I Lacur was a poor kid (lacur). It matched with his name that was I Lacur. He only had a yard, and a broken hut. The hut was built by straw; the walls were made from palm leaves. In the rainy day, I Lacur was busy looking for leaves to cover his leaked hut.

Even though his yard only filled with a broken hut, he diligently cleaned it. Every time I Lacur came from traveling, he always took a sickle to clean the yard and planted spinach, eggplant and chili. He also did not forget to repair the damaged roof of his hut. The trash was made 
into a pit and then burned. Every morning, I Lacur cleaned his hut and around the yard. After cleaning, I Lacur went ourside. That was his daily activity.

I Lacur was a diligent child. He was not a mischievous boy. Instead, his friends often bullied him, but he was never angry, or even fought. If anyone told him to do something, he never refused. One day after I Lacur finished cleaning the hut and yard, he went out to look for vegetables. When they reached the road, their friends came, and they all bullied him. Some mocked him, spat on him, and hit him, but he said nothing. There was one of his most naughty friends, namely I Klaleng. All of a sudden, there was a broken kite. All children run after the kite.

The kite was stuck on a tree. I Klaleng was the first one climbing the tree. His friends also climbed the tree. Without realizing, I Klaleng stepped on a weathered and dry branch. I Klaleng fell from the tree and fainted

Seeing I Klaleng fell, his friends ran away leaving him. He saw it and he helped I Klaleng quickly, then brought him home. Arriving at I Klaleng house, it surprised his father and mother to see his son was in a sling by I Lacur. It confused I Klaleng's parents. They lift him in and got him a treatment. A few moments later, I Klaleng realized and felt pain. After I Klaleng woke up, then I Lacur talked to his mother "Ma'am, now I want to go home". Mrs. I Klaleng answered, "Lacur, wait a minute, I will give you money". I Lacur answered, "no need ma'am". After that, he came home. On his way, he saw old grandmothers holding sticks and carrying lots of things and a basket of yam. I Lacur saw her, and wanted to help her bring the basket to her house. I Lacur asked Grandma, "where did I put these items?" Grandma said "just lay it here, son". After that, he wanted to go home, but the grandmother wanted to give him a yam and asked him to wait. Then, he returned home with a happy heart bringing a yam. When he got home, he cooked vegetables filled with yam. Before he ate, he made five banten Saiban (daily offering to God, which is made after cooking or before cooking). He presented in the kitchen, merajan (house temple), yard, well, and in front of the house. After finishing the prayer, he only ate the vegetable. Every night he felt very lonely.

The next day, he went hunting in the middle of the forest to look for vegetables. He saw a house that was spotless and filled with a variety of flowers. That house was surprised him. The one who owned the house was Ki Dukuh Sakti. When I Lacur was daydreaming, suddenly Ki Dukuh Sakti came out. Seeing I Lacur standing, Ki Dukuh Sakti called him. $\mathrm{He}$ was very surprised but saluted $\mathrm{Ki}$ Dukuh Sakti. He said " My name is I Lacur". Ki Dukuh Sakti asked him, "Where is your house?" I Lacur said, " I do not have a house". Ki Dukuh Sakti offered him to stay with him. I Lacur accepted Ki Dukuh Sakti's offer, and he stayed there. According to people's stories, Ki Dukuh Sakti was powerful and smart. At Ki Dukuh Sakti's house, he acted diligently. He worked to hoe, sweep, got water and cook. Jero Dukuh loved him greatly. At night, I Lacur learned literature and religion from him. I Lacur was very pleased to learn all the lessons given by $\mathrm{Ki}$ Dukuh Sakti and he became smart. In his adultery, he learned the science of treatment from Ki Dukuh Sakti. Although he had lived there, he did not forget his hometown. Once every week, he came home and cleaned his house until it was clean. After that, he went back to Ki Dukuh Sakti's house. One day I Lacur came home. On the way, he saw a child who was sitting crying in pain. I Lacur approached the child, and 
apparently, the child's feet were bitten by snakes. It was swollen and he could not walk. He carried the child to his home. He asked the child to sit, and not allowed him to sleep. I Lacur quickly looked for drugs to antidote venom from the snake. Then the swelling and pain were gone. The child felt very pleased and thanked him for his help. In the afternoon, I Lacur returned to Ki Dukuh Sakti's house, and he told him about his journey. Jero Dukuh was happy and said, "Well-done! If you see people in need you must help them and do not expect a reward, because one day you will find happiness because God Knows all of our deeds. People who like to help others will have a lot of friends". Later on, it was told that Jero Dukuh heard the news of Ida Raden Galuh, who was seriously ill. He gave orders to I Lacur, "I Lacur, I heard the news that Ida Raden Galuh was very sick. Many experts were failed to cure Ida Raden Galuh. Now please go to the palace and treat Ida Raden Galuh. I will give you the most potent medicine because it can cure any illness". Ki Dukuh Sakti gave him medicine and oil. He said the medicine for a traditional drink and the oil for massaging. Then, I lacur went to palace with the stuffs. He arrived at the palace and many people already there. They were men of the palace. All of them were unhappy seeing him and they asked him, "hey Lacur what are you looking for? Don't you know that Raden Galuh is sick?" He answered, "I came to treat Ida Raden Galuh" Everyone underestimated him. They talked back, "you are so naive I lacur, even the powerful man can not cure him let alone a nobody like you" The arrival of I Lacur was heard by the king, and he was asked to meet him. The king asked, "are you coming here to treat Raden Galuh? "I Lacur answered,
"Yes it is true that I come here to treat Ida Raden Galuh". The king then asked him to do so, and wished him to succeed healing his son.

It was told that Ida Raden Galuh forgot his memory and forgot to be himself at all times. His mother cried while hugging her son. It was said that I Lacur treated Raden Galuh as instructed by his teacher. After Raden Galuh was given treatment followed by giving spells, he was recovered and found back himself. The King was very pleased, and Raden Galuh woke up from his sleep, everyone felt very pleased. All were surprised by I lacur's power. As the king's order, I Lacur could not be home yet. In short, not until three days, Raden Galuh had been as healthy as before. King's wife and the ladies were all very pleased. The king paid the debt and said, "Lacur, now you become a man of the palace and I will give you rice fields, gardens, and yards containing houses. Now you live here and I will change your name, I give you the name "I Subagia". That is the king's order.

From the analysis of Satua I Lacur synopsis, it reflects that the attitude of helping each other is a must deeds to do because man as a social creature can not live without others.

2. Education values in Satua I Lacur

a. Educational Value Tattwa

Tattwa is derived from the Sanskrit word "Tat" meaning "it" and "twa" which means with me. The word tattwa can be interpreted as keituan (phylosophy). Keituan is about the truth of God. Tattwa is one of the three basic framework of Hindu religion, namely Susila and ceremony (Sudani, 2017). Based on the depiction of the main character, there is a message/teaching that the author wants to convey. The protagonist is gentle, never angry, innocent, so he was always in a calm state. It showed 
that the qualities of wisdom that means human beings who can master his mind (berwiweka). Good deeds and bad deeds, likes and hate are thoughtful traits to control every human motion (Tri Kaya). It towards the tendency of worldly passions resulting human destruction, the selfcontrol of every human movement, a mind that classifies his behavior to make a difference of deeds, so that self-balance takes place automatically between a human relationship with human, human relationship with every creature life and human relationships with his belief in God.

In the story, I Lacur had an innocent character that loves to help. The value of Tattwa is work sincerely (yadnya) to get phala and asubha karma.

The above opinion can be analyzed based on the following contents of sloka book Bhagavad Gita:

\section{tasmad aksitahsatam}

karyam karma samachara

to asakto hy achiram karma

param apnoti purushah. (BG. III. 19)

Translation

From that, do all the work

As a duty without the benefit

Work without personal gain

Bring people to the highest happiness.

(S. Pendit, 1967:94)

Na Prahrisyet greenways Prapya

No Dvijet prapya Cha Pryam

Sthitabhuddim Sour Mudho

Brahmavid brakmi shittah (BG. V.

20)

Translation

$\mathrm{He}$ who does not rejoice in accepting joy

And also did not grieve received grief

Stay calm and stand the faith

Knowing Brahman is united with

Atman. (S. Pendit, 1967:151)
The above point shows an increase and a passion for the teaching values of karma marga. It shows how to connect yourself with work without measuring the reward. The value of the karma marga as a benchmark of understanding brings the tasks that must be implemented in life and beryadnya because dharma refers to the human attitudes. Whether it is good or bad. So, in society, it is the dharma that be the foundation and as a good reference for achieving happiness in this world.

The value of tattwa is about knowledge when he proved himself to be able do cure Ida Raden Galuh from his illness. The value of education supporting by the human sciences can develop the potential existing within him so that there will be a learning outcomes in the form of analyzing experience and trying to solve their problems.

b. The Value of Ethical Education Ethics is a form of self-control in daily living. Human beings are homo socius beings. They can not live alone, they always share with others. Man lives well and man will only have meaning when he lives with other human beings in the community (I Gede Sura, 1985). Further in the book entitled Vedanta Gema, freedom is mentioned as an ethics that is not to kill, hurt, and love your neighbor as yourself.

The doctrine of ethics or tatasusila as good and righteous conduct for the happiness of life and the harmony of the relationship between man and God Almighty, between human beings, man with the universe and His Creation (Title, 1996). It is the importance of ethics in human life that Hindu religion makes ethics as a solid 
basis of its teaching. It is in the Three Framework of Hindu Religion comprising Tattwa (philosophy), Ethics (Susila) and Ritual. The teachings of ethics in Hinduism including truth, affection, goodness, diligence, and morality.

In the story of I Lacur, there are many ethical values which are also easy to understand. The ethical value in the story is, I Lacur was bullied by his friends, beaten, spat on and his friends were always fierce and rude to him. It can be quoted as the existence of asuri sampat value and sad ripu which is the characteristics of human selfliteracy. Bhagavad gita chapter XVI Sloka 4 explains the close relation of sad ripu ie, kama (desire), krodha (Anger), lobha (greedy), moha (confusion), Mada (drunk), matsarya (envy). All these are the enemies that exist in each human being; therefore, sad ripu belongs to the character of asuri sampat. Then, it is the traits conquered/controlled so that people always strive to do good in every action and strife. The enemies in man are only human beings who can conquer/control because people have understood and are wary of the actions posed by the enemies.

The ethical educational value in the story I Lacur is the value of asuri sampat and sad ripu which should be able to be executed by humans. The character of asuri sampat and sad ripu owned by I Klaleng was a symbol in human beings. The enemies in the human being can arise. If human consciousness declines can lead to deeds toward unpraiseworthy behavior the influence of the enemies, (asuri, sampat and sad ripu ) then it is very necessary to control those enemies by understanding religious teachings.

The above analysis mentions ethical values of karmaphala, tat twam asi and self introspection. It can be deployed that Hinduism believes in the teachings of karmaphala and tat twam asi. Besides, it is believed that the doer will accept the consequence of the deed. Every karma has result (phala). The teachings of the karma phala is believed to cause reincarnation from the asubha karma (bad deeds). Furthermore, the deeds arising from subha karma (good deeds) will achieve happiness. The efforts of the achievement of selfimprovement must be carried out continuously by humans, because in this life aims to improve from bad deeds to be good deeds. In the book of Sarasamuccaya mentioned:

Manusah sarva bhutetsu, ikang janma wwang

Juga wenang gumayaken ikang subha, asubha karma,

Kumena panentasakena ring subhakarma

Juga ikang subha karma phala

ring dadi wwang (S.S.2)

Translation

Among all living things,

Only born human

Who can carry out good or bad deeds,

Merge into good deeds,

All those bad deeds,

Such is the point of being human (Kadjeng, 1993: 5)

From the above quote sloka, only human being can do good deeds, not animals or plants. Humans are taught to carry out the ethical values in Hindu teachings namely tat twam asi, self-control, selfintrospection, which directly encourage humans to be diverse, so that we get physical and spiritual 
happiness. In Satua I Lacur, I Lacur's behavior depicts noble deeds. He always behaves under the ethical teachings of the Trikaya Parisudha namely three good deeds, including manacika, wacika, and kayika which means to think, say, and do good. It united the three ethics in him and in the mirror of all his actions in socializing with others.

3. The steps taken by the teacher in teaching the values of Religious Education.

Besides teaching, teacher is also as a medium in teaching. The teacher plays an important role in the teaching learning process. The teacher as an educator is a determining factor for the success of any educational endeavor. Efforts to teach Hindu religious education to foster the personality and behavior of elementary school students in the city of Denpasar, use a variety of lessons that have been adapted to the material and grade level. From the results of the study religious teachers and class III teachers use narrative patterns in explaining subjects including Hindu religious lessons.

The steps taken by the teacher towards implementing Hindu religious education values in Satua I Lacur are:

a. The teacher tells Satua I Lacur in front of the class

The first step taken by a teacher in the application of Satua I Lacur in $3^{\text {rd }}$ grader of elementary schools is able to tell Satua I Lacur in front of the class. This is intended to boost the learning spirit of students. It is one way to motivate so that the application of educational values can be implemented to the maximum.

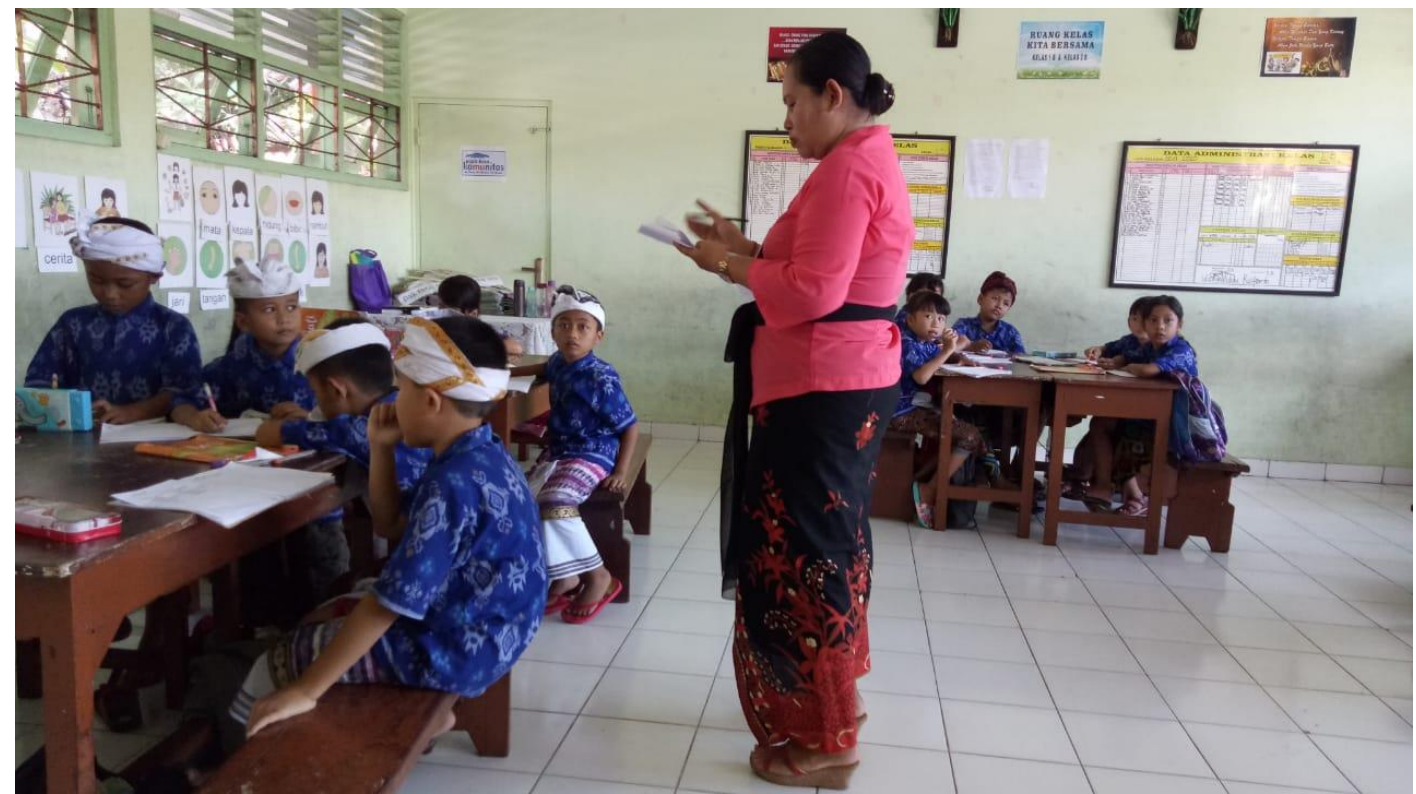

Figure 1. Learning at SDN 12 Sanur Denpasar

b. Encourage children to share about Satua I Lacur in front of the class. The next steps can be done is encouraging students to come forward and tell the class about Satua I Lacur. This is implemented so that a student can mentally sharpen and dare to perform in front of friends to tell stories. Besides elementary school students in Denpasar, especially third grade are very enthusiastic when teaching is given by telling satua (story). 


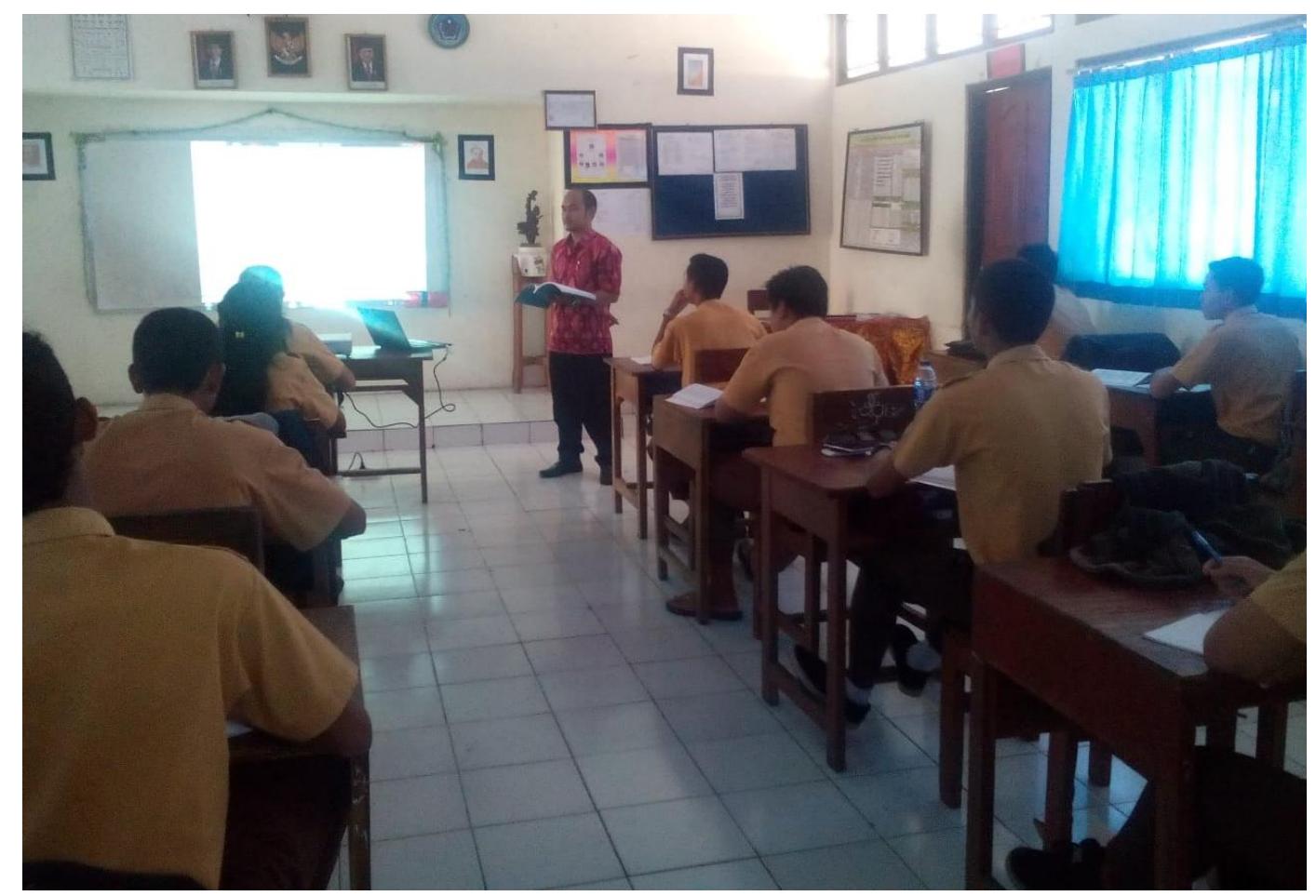

Figure 2. Learning at SMAN 1 Baturiti Tabanan

Besides being able to boost learning spirit, this teaching technique can also assess students' abilities in presenting (explaining)
Satua I Lacur then the next stage is to measure students' understanding in its application.

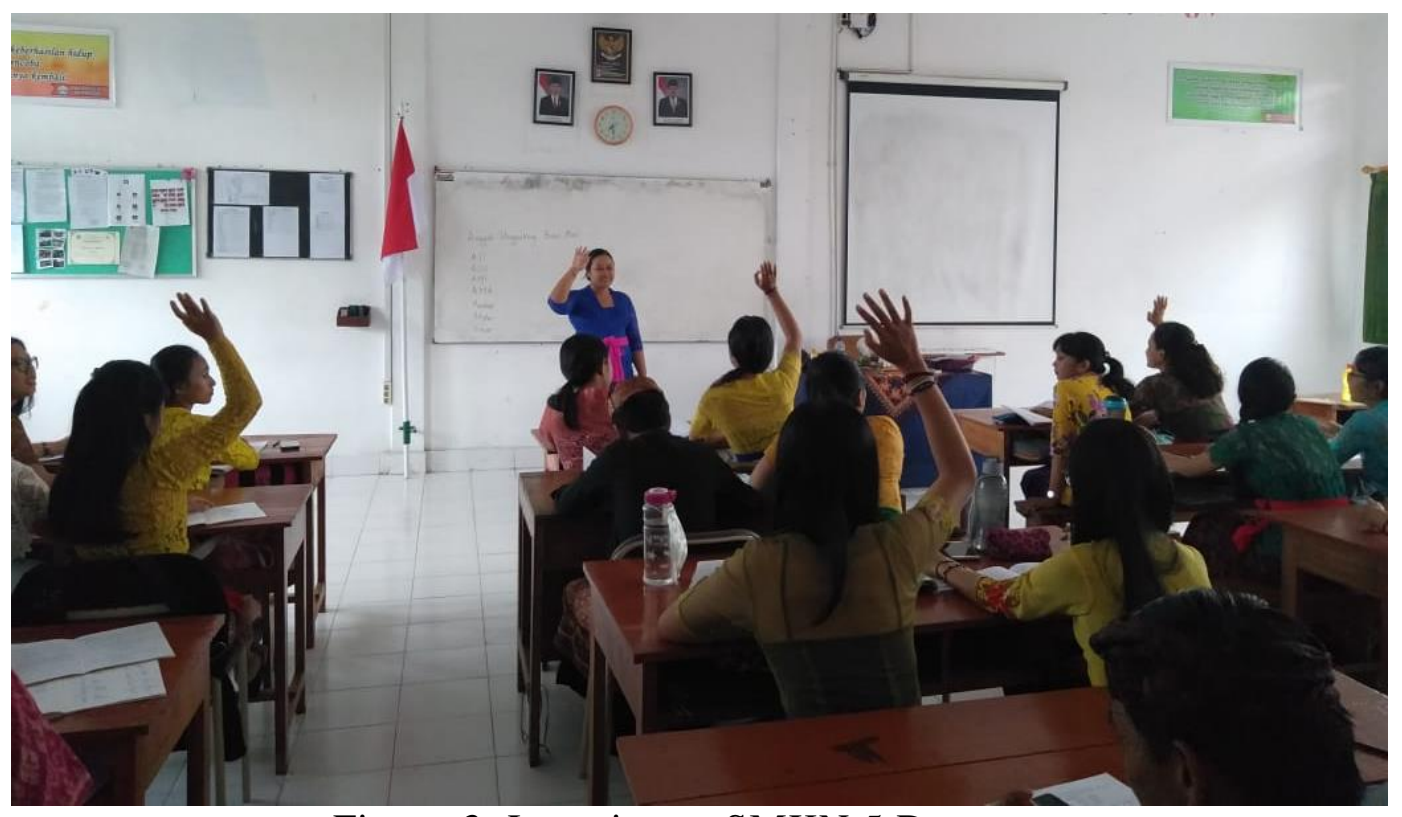

Figure 3. Learning at SMKN 5 Denpasar

c. Education values in Satua I Lacur Here the teacher's role is more dominant. Where the teacher shows and explains values, students can apply that under the explanation in research problem no. 2 explaining the values of education in Satua I Lacur 
1) The value of tatwa education Students must implement the teachings without expecting the reward just like I Lacur who is innocent and love to help others. The value of education tattwa is the existence of work sincerely (yadnya) thus obtaining phala and subha karma. The value of tattwa education in Satua I Lacur is seen when I Lacur helps others. As it is revealed in the story as follows.

Dugase ento ada layangan pegat. Cerik-cerike makejang melaib nguber layangan, layanganne ento ngingsut dipunyan kayune. I Klaleng tangu malu mongkod punyan kayune ento. Timpalne masih bareng merebut, I Klaleng ulung meglebug tur niwang. Tingalina baan I Lacur I Klaleng ulung lantas enggal jagjagina baan I Lacur.

Translation :

There was a kite that broke up. All the children run after the kite. The kite was stuck in a tree. I Klaleng was the first one climbing the tree. His friends also scramble. I Klaleng quickly climbed up, and without realizing, he stepped on dry branches of a wooden tree. Then, I Klaleng fell from a tree and fainted. I Lacur saw this, he approached and carried him to home. Arriving at I Klaleng's house, it surprises his father and mother seeing his son fainted and carried by I Lacur. He put I Klaleng on his bed and massage his legs.

Teked dirurunge, tepukina anak tua matungked nyuun sok misi kesela sarat. Tingalina teken I Lacur lantas jagjagina, laut ngomong" Dadong mai titiang ngabaang soke ento". Lantas jemakina suuna sokne baan I Lacur anak odah kendel pesan jemakina.

Translation:

Arriving on the road, I Lacur saw a grandmother holding a stick and a basket full of yam. I Lacur approached and said, "Let me bring the basket, Grandma." Then the basket was held by I Lacur. The grandmother felt happy.

Sedek dina anu I Lacur nepukin ada anak negak ngeling aduhaduh. Ditu lantas paekina tur takonina, anake ento ngeling ngorahang batisne gutil lelipi, sube beseh tur tusing dadi baan mejalan. Ditu I Lacur ngalih kupas lantas bedbeda batis anake ento. Suud keto lantas sangkola ajaka kepondokne. I Lacur encol ngalih lakar ubad lakar anggona ngubadin batis anake ento.

Translation:

One day I Lacur saw a child sitting while crying in pain. Then, the child was approached and carried to his home. The child said that his foot was poked by a snake. It was swollen and he could not walk. There I Lacur looked for banana fronds and bandaged the boy's feet. I Lacur brought him home and quickly looked for the medicine to cure the boy's feet.

Kacrita jani Ki Dukuh mireng orta buat Ida Raden Galuh sungkan banget, lantas dane ngandikain I Lacur. "Ih cening Lacur, bapa ningeh orta buat Ida Raden Galuh Daha 
sungkan banget", makudangkudang balian nambanin Ida Raden Galuh, ne bapa maang cening ubad utama. Yadin namun apa sarat sakit anake, yen ene anggo ngubadin pedas seger, "keto pangandikane $K i$ Dukuh lantas I lcur icene serbuk, lengis teken manik. Dit lantas I Lacur mapamit mejalan ngabe ubade ento ke Puri.

Translation:

It was told that Ki Dukuh heard the news of Ida Raden Galuh seriously ill. He gave orders to I Lacur, "O you Lacur, I heard the news saying that Raden Galuh is seriously ill". There are many medical experts to treat Raden Galuh but they are failed. I will give you the potent medicine. No matter how bad the person's illness if we give this medicine, that person can be cured. That is the advice of Ki Dukuh and I Lacur went to the palace bringing the medicine.

The value of tattwa contained in Satua I Lacur is helping each other of God's creature. It is an obligation because humans are created better than other living creature besides human is a social creatures that can not live withour others. It can be drawn that the value of sincere work (yadnya) to get phala from subha karma. The story says that I Lacur always worked diligently. Where the responsibility must be carried out seriously to get happiness. The value of yadnya (sincerity) and the dharma teachings (swadharma) in carrying out their duties so that I Lacur get happiness in the form of Yadnya Teachings and Dharma Teachings. It is an obligation or dharma of Hindu devotion, because from birth it has a debt called Tri Rna with the elaboration Panca Yadnya. The debt of life to the Gods is paid by carrying out Dewa Yadnya and Bhuta Yadnya. The debt of knowledge to $R s i$ (Teacher) by doing Rsi Yadnya, so that Hindus believe that implementing a yadnya will bring physical and spiritual happiness in social life both on a scale and noetic scale.

2) The value of ethical education A child in daily life shows good ethics and behavior. The doctrine of ethics or tatasusila as good and righteous conduct for the happiness of life and the harmony of the relationship between man and God Almighty, between human beings, man with the universe and His Creation (Title, 1996). It is the importance of ethics in human life that the Hindu religion makes ethics as a solid foothold of its teaching that is in the Three Framework of Hindu Religion comprising Tattwa (philosophy), Ethics (Susila) and Ritual. 


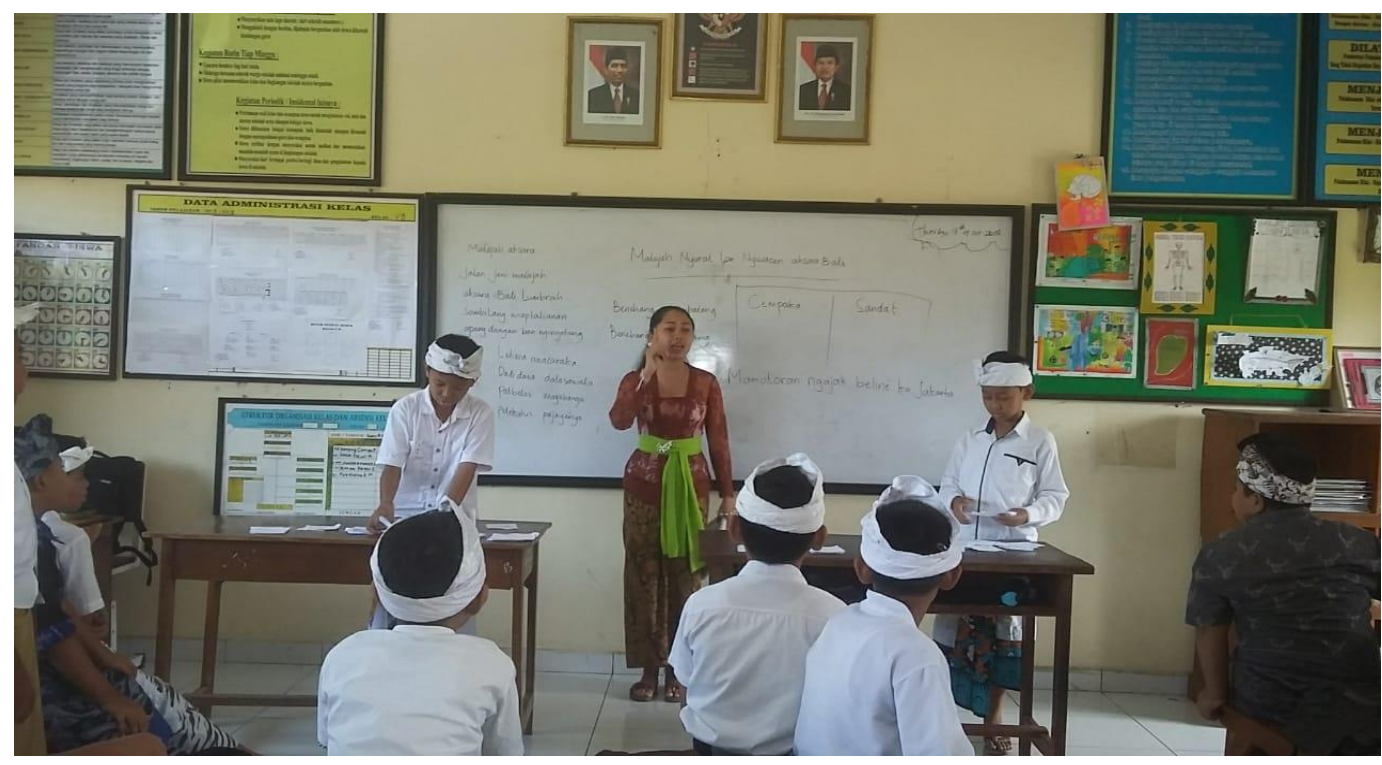

Figure 4. Learning at SDN 17 Dauh Puri Denpasar

In the story of I Lacur, there were many ethical values in the story, which is also easy to understand. The ethical value in the story section was when I Lacur bullied by his friends, beaten, spat on and his friends were always fierce and rude to him. It can be quoted that the value of asuri sampat existence and sad ripu as the characteristics of human selfliteracy. In Bhagawadgita Chapter XVI Sloka 4 explains that there is a close relationship between sad ripu, which is an enemy that exists in every human being; therefore, sad ripu belongs to asuri sampat, so it should be conquered to make humans always try to do good deeds in every action.

The ethical educational value in the story of I Lacur is the value of asuri sampat and sad ripu which should be able to be executed by humans. The nature of asuri sampat and sad ripu by I Klaleng is a symbol in human beings. The enemies in human being can arise. If human consciousness declines, it can lead to unpraiseworthy behavior for the influence of the enemies, (asuri sampat and sad ripu) then it is very necessary for those enemies controlled within the understanding of religious teachings. Ethical values contained teachings karma phala, tat twam asi and selfintrospection. It can be interpreted that Hinduism believes in the teachings of karmaphala and tat twam asi, the doer will accept the consequence of the deed. Every karma has a result (phala), because the teaching of the karma phala is believed to cause reincarnation to improve theirselves from asubha karma (bad deeds) where deeds arising from subha karma (good deeds) will achieve happiness. The efforts of the achievement of selfimprovement must be carried out continuously by humans. Because in this life, it aims to improve from bad deeds to be good deeds. In the book sarasamuscaya it says: 
Manusah sarva bhutetsu, ikang janma wwang

Juga wenang gumayaken ikang subha, asubha karma,

Kumena panentasakena ring subhakarma

Juga ikang subha karma phala ring dadi wwang (S.S.2)

Translation

Among all living things,

Only born human

Who can carry out good or

bad deeds,

Merge into good deeds,

All those bad deeds,

Such is the point of being

human (Kadjeng, 1993: 5)

From the above quote sloka, only human can do good deeds not animals or plants, thus humans are taught to carry out the ethical values in Hindu teachings namely tat twam asi, self-control, selfintrospection, which directly values These values encourage humans to be diverse so that we get physical and spiritual happiness.

d. Encourage children to behave like Satua I Lacur

Satua I Lacur teaches a lot of educational values, especially ethical values where the attitude needs to be imitated by students. It taught them to be a social person and help one another without discrimination. Likewise, social status is taught not to choose friends to mingle and help each other in the classroom.

Implementing Hindu religious education values is aimed to form students' abilities as follows.

1) To develop and improve the quality of Sradha and devotion through giving, fertilizing, observing and practicing religious teachings.
2) Build Hindu people who can realize the values of Moksartham Jagathita in their lives. In the above ways, it reflects the existence of a tool in solving problems and training to give effect to their souls. Satua I Lacur is a good medium of teaching effort by instilling the Hindu education and character education. Thus, it will be able to change attitudes in behavior both in the school environment, in the family and society.

Meanwhile, from observations by researchers, it was found that Hindu religious teachers presenting the story in front of the class then continued with the teacher encourage students to come in front of the class and retell the story. Later, it was followed by the teacher explaining the educational values in Satua I Lacur, and finally, the teacher directs the students to behave like the character of I Lacur.

Thus based on observations and interviews with Hindu religious teachers in instilling educational values in Satua I Lacur, it can be concluded that: First, teacher tell Satua I Lacur to the class with the expectation students' learning enthusiasm would be fun because mesatua will make students more remembering the material taught. Second, it encourages students to appear in front of the class and retell Satua I Lacur. This was done to find out whether the students already understand Satua I Lacur. Third, teachers explain the educational values in Satua I Lacur. It makes students understanding what value is 
worthy in Satua I Lacur and finally the teacher directs students to behave like I Lacur character.

\section{CONCLUSION}

Structure Satua I Lacur consists of theme, setting, plot, characterization, and mandate. The theme in Satua I Lacur is a good person, diligent and helpful. While the setting is Lacur's hut, forest, I Klaleng's house I, Ki Dukuh Sakti's house, and Palace. The plot starts from the incident I Lacur who was bullied by his friends and ends with treating Ida Raden Galuh. Followed by the characterization of the main character that is I Lacur. The moral value found in the Satua I Lacur is help each other sincerely.

Educational value of tattwa, the nature of wisdom which means humans as creatures capable of mastering their thoughts about good deeds and bad deeds, likes and hates are wise qualities to control every human movement (Tri Kaya) toward the tendency of worldly desires. In the story, I Lacur loves to help others. The value of education is that there are values of work sincerely (yadnya) to get phala and subha karma. So, dharma people become the foundation of the society based on happiness and the reference of good karma to achieve happiness in this world. The value of the tatwa education given in story is knowledge, I Lacur proved the knowledge he gained when treating Ida Raden Galuh from his illness. The value of tattwa education given in story is science, I Lacur proved the science that he got when treating Ida Raden Galuh from his illness. The value of education propsed that though the foundation of human sciences, it can develop the potential existing within him so that they will learn outcomes in the form of analyzing experience and trying to solve their problems.

The ethical values in Hindu teachings are tattwam asi, self-control, self-introspection, which directly encourage these values for humans to be diverse, to get physical and spiritual happiness. The ethical value in the story, I Lacur was bullied by his friends, beaten, spat on and his friends were always fierce and rude to him. The ethical values of the values of asuri sampat and sad ripu are the characteristics of human self-grasping, so it should conquer these qualities / controlled so that humans always strive to do good deeds in every action. The enemies in man are can be conquered / controlled only by theirselves because people have understood and are wary of the enemies actions posses by human being.

\section{REFERENCES}

Dias Febriadiana, N. M. (2018). Teks Satua Betara Watugunung Dalam Cerita Rakyat Daerah Bali: Analisis Struktur dan Fungsi. Humanis, 65. https://doi.org/10.24843/jh.2018.v22. i02.p10

Duija, I., \& Dewi PF, K. (2019). Position of Satua or Bali Myth in Socio-Cultural Change in Society. https://doi.org/10.4108/eai.27-42019.2286851

Fakhruddin, I. S. (2019). The Impact of NonFormal Education in Community Development:A Case Study in Pati, Indonesia. International Journal of Innovation, Creativity and Change, 5(5), 339-352. Retrieved from https://www.ijicc.net/images/vol5iss5 15525_Fakhruddin_2019_E_R.pdf

I Gede Sura. (1985). Pengendalian Diri dan Etika Dalam Ajaran Agama Hindu. Jakarta: Hanuman Sakti.

Lestiawati, S., \& Muthmainnah, R. (2019). The Influence of Firing Line Active Learning Approach on Students' Motivation in Learning Mathematics. In Proceedings of the Proceedings of 
the 2nd International Conference on Local Wisdom, INCOLWIS 2019, August 29-30, 2019, Padang, West Sumatera, Indonesia. EAI. https://doi.org/10.4108/eai.29-82019.2289157

Mustika, I. K. (2019). Pemanfaatan Teks Bacaan Satua Bali Dalam Menumbuhkan Budaya Literasi Dan Pembentukan Karakter Pada Siswa Sekolah Dasar. Adi Widya: Jurnal Pendidikan Dasar. https://doi.org/10.25078/aw.v2i2.965

Sari, D., Rahmatunnisa, S., Bahfen, M., \& Fauziah, F. (2019). Improving Visual Spatial Ability of Children 3-4 Years
Through Playing Lego. In Proceedings of the 2nd International Conference on Local Wisdom, INCOLWIS 2019. EAI. https://doi.org/10.4108/eai.29-82019.2289134

Sudani, N. K. (2017). Pemahaman Konsep Tattwa Dengan Ketrampilan Upakara Bhuta Yadnya. Dharmasmrti: Jurnal Ilmu Agama Dan Kebudayaan. https://doi.org/10.32795/ds.v17i02.93

Titib, I. M. (1996). Veda Sabda Suci Pedoman Praktis Kehidupan. Surabaya: Paramitha. 